\title{
A relative method for measuring nitric oxide (NO) fluxes from forest soils
}

\author{
Jiaqi Wang ${ }^{\mathrm{a}, \mathrm{b}}$, Xiaoshan Zhang ${ }^{\mathrm{a}, *}$, Zhangwei Wang ${ }^{\mathrm{a}}$, Ronghua Kang ${ }^{\mathrm{c}}$ \\ a Research Center for Eco-Environmental Sciences, Chinese Academy of Sciences, Beijing 100085, China \\ b University of Chinese Academy of Sciences, Beijing 100049, China \\ ${ }^{c}$ Norwegian University of Life Sciences, postbox 5003, Ås 1432, Norway
}

\section{H I G H L I G H T S}

- We presented and tested a relative method for measuring NO fluxes from forest soils.

- The soil water samples could be kept in room temperature for several days or more for NO analysis.

- The calculated NO fluxes agreed well with the chamber-based values.

- This method provides a sound methodological basis for interpreting NO flux variations in the field.
G R A P H I C A L A B S T R A C T
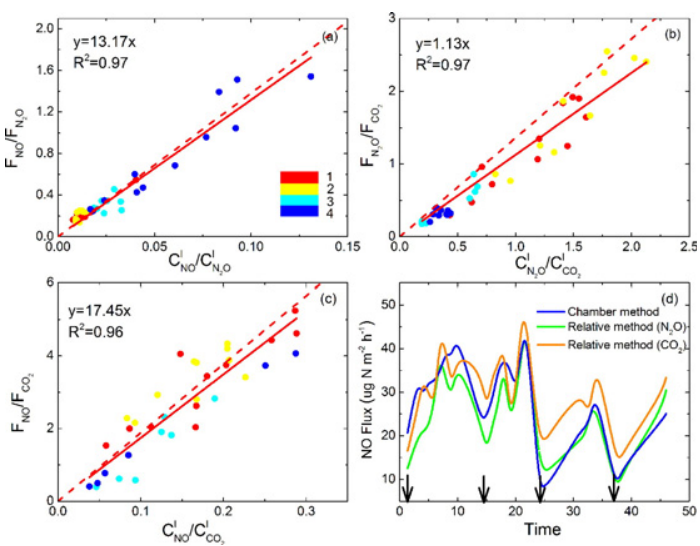

\section{A B S T R A C T}

Many forest ecosystems in the world are suffering from high load of nitrogen $(\mathrm{N})$ deposition and acting as potential contributors to atmospheric nitric oxide (NO), which regulates the oxidative capacity of the troposphere. However, the observation of NO flux with traditional dynamic chamber method is laborious in the forest ecosystem, particularly when the electric power generation system is unavailable. In this work, a relative method based on Fick's law of diffusion was developed to measure NO fluxes from forest soils. This method describes the relationship between $\mathrm{NO}$ and other trace gases, such as $\mathrm{N}_{2} \mathrm{O}$ or $\mathrm{CO}_{2}$, concerning gas fluxes and gas concentration gradients between the uppermost soil layer and the atmosphere. This relative method can be expressed as two forms: based on the directly obtained soil gas and based on the equilibrium gas at soil water surface. To testify the applicability of this method, both laboratory and field experiments were conducted with soil from an Nsaturated subtropical forest in Southwestern China. The results demonstrate that the NO fluxes measured based on the later form agreed well with those observed by chamber method, with the deviation rates of around $9 \%$ and $30 \%$, respectively. In conclusion, this relative method provides a sound methodological basis for interpreting NO flux variations in the field, especially in N-saturated forest ecosystems, and allows an improvement of statistical N-budget in the world.

c) 2016 Published by Elsevier B.V.

\footnotetext{
* Corresponding author.

E-mail address: zhangxsh@rcees.ac.cn (X. Zhang).
} 


\begin{tabular}{|c|c|}
\hline \multicolumn{2}{|c|}{ Nomenclature } \\
\hline $\mathrm{C}_{0}$ & gas concentration in the atmosphere $\left(\mu \mathrm{g} \mathrm{m}^{-3}\right)$ \\
\hline $\mathrm{C}_{\mathrm{g}}$ & gas concentration in the uppermost soil layer $\left(\mu \mathrm{g} \mathrm{m}^{-3}\right)$ \\
\hline$C_{1}$ & dissolved gas concentration in the soil water $\left(\mathrm{mol} \mathrm{L}^{-1}\right)$ \\
\hline $\mathrm{C}_{\mathrm{vg}}$ & $\begin{array}{l}\text { gas concentration in the headspace of the soil water } \\
\text { sampling vial ( } \mathrm{mol} \mathrm{L}^{-1} \text { or atm) }\end{array}$ \\
\hline $\mathrm{C}_{\mathrm{vl}}$ & $\begin{array}{l}\text { dissolved gas concentration in the solution collected in } \\
\text { the soil water sampling vial }\left(\mathrm{mol} \mathrm{L}^{-1}\right)\end{array}$ \\
\hline$C^{*}$ & $\begin{array}{l}\text { equilibrium gas concentration upon the soil water sur- } \\
\text { face }\left(\mu \mathrm{g} \mathrm{m}^{-3}\right)\end{array}$ \\
\hline $\mathrm{C}_{\mathrm{s}}$ & directly obtained soil gas concentration $\left(\mu \mathrm{g} \mathrm{m}^{-3}\right)$ \\
\hline$\Delta C$ & $\begin{array}{l}\text { concentration difference between } C_{0} \text { and } C_{g}\left(\mu \mathrm{g} \mathrm{m}^{-3}\right) \text {, } \\
\text { expressed as two forms according to the soil gas condi- } \\
\text { tions }\left(\Delta C^{*} \text { or } \Delta C^{s}\right)\end{array}$ \\
\hline $\mathrm{D}_{0}$ & gas diffusion coefficient in the atmosphere $\left(\mathrm{cm}^{2} \mathrm{~s}^{-1}\right)$ \\
\hline$\rho_{\mathrm{b}}$ & dry bulk density of the soil $\left(\mathrm{g} \mathrm{cm}^{-3}\right)$ \\
\hline$\rho_{\mathrm{d}}$ & particle density $\left(\mathrm{g} \mathrm{cm}^{-3}\right)$ \\
\hline $\mathrm{D}_{\mathrm{s}}$ & gas diffusion coefficient in the soil $\left(\mathrm{cm}^{2} \mathrm{~s}^{-1}\right)$ \\
\hline $\mathrm{F}$ & soil-atmosphere exchange flux ( $\left.\mu \mathrm{g} \mathrm{m}^{-2} \mathrm{~h}^{-1}\right)$. \\
\hline $\mathrm{K}_{\mathrm{H}}$ & Henry's law constant $\left(\mathrm{mol} \mathrm{atm}-1 \mathrm{~L}^{-1}\right)$ \\
\hline $\mathrm{K}_{\mathrm{H}}^{\circ}$ & Henry's law constant at $298.15 \mathrm{~K}\left(\mathrm{~mol} \mathrm{~atm}{ }^{-1} \mathrm{~L}^{-1}\right)$. \\
\hline M & relative molecular mass for observed gas $\left(\mathrm{g} \mathrm{mol}^{-1}\right)$ \\
\hline$V_{\mathrm{vg}}$ & final gaseous volume in the soil water sampling vial (L) \\
\hline $\mathrm{V}_{\mathrm{vl}}$ & final aqueous volume in the soil water sampling vial (L) \\
\hline $\mathrm{z}$ & $\begin{array}{l}\text { soil vertical distance from the soil gas or soil water sam- } \\
\text { pling site to the soil surface }(\mathrm{cm})\end{array}$ \\
\hline$\theta_{\mathrm{g}}$ & gas-fill porosity in the soil $\left(\mathrm{cm}^{3} \mathrm{~cm}^{-3}\right)$ \\
\hline$\theta_{\mathrm{t}}^{\mathrm{s}}$ & total porosity in the soil $\left(\mathrm{cm}^{3} \mathrm{~cm}^{-3}\right)$ \\
\hline$\omega$ & gravimetric water content $\left(\mathrm{mL} \mathrm{cm}^{-3}\right)$ \\
\hline
\end{tabular}

\section{Introduction}

Nitric oxide (NO), a highly reactive trace gas, plays a crucial role in tropospheric chemistry (Crutzen, 1979; Ludwig et al., 2001; Medinets et al., 2015). Due to the fast chemical conversion between NO and $\mathrm{NO}_{2}$, which typically occurs within seconds to minutes, $\mathrm{NO}$ and $\mathrm{NO}_{2}$ are commonly considered as the single quantity $\mathrm{NO}_{\mathrm{x}}$. It determines the lifetime of many trace gases and regulates the oxidizing capacity of the troposphere. Soils are a major source of atmospheric NO (Davidson and Kingerlee, 1997; Galbally and Roy, 1978). It is reported that with increasing $\mathrm{NH}_{3}$-volatilisation from agriculture, many forest ecosystems have received large amounts of N-deposition and acted as potential contributors to the tropospheric NO burden (Buhlmann et al., 2015; Skiba et al., 1998; Venterea et al., 2003).

Previous NO flux measurements from forests were, however, imbalanced in regions under investigation. Most NO flux measurements have been proceeded in Europe and United States (Erickson and Perakis, 2014; Luo et al., 2012; Schindlbacher et al., 2004; van Dijk and Duyzer, 1999); while the studies were limited in Asia (Li et al., 2007; Nishina et al., 2009; Purbopuspito et al., 2006), where most field measurements were centered on croplands (Mei et al., 2009; Zhang et al., 2016a; Zhang et al., 2016b). Given the limited experiments involved, the observed forest NO fluxes in Asia are far from representative of its biome. Previous works have reported that the N-deposition rate in China was higher than those in the United States and Europe, with the average values of $12.89 \mathrm{~kg} \mathrm{~N} \mathrm{ha}^{-1} \mathrm{yr}^{-1}$ (Lu and Tian, 2007). Considering the diverse forest types and the large $\mathrm{N}$-deposition in Asia, especially in China, more observations are undoubtedly needed to form the basis for upgrading NO flux from site scales to regional scales.

To date, the dominant method for NO flux measurements is the dynamic chamber method (Li et al., 2008; Pilegaard et al., 2006; Wolf et al., 2011b; Wu et al., 2010). However, this method proves defective in the field, especially in the forest ecosystems. Because, in most instances, the electric power generation system for the operation of pump and on-line NO detection instrument is unavailable. Therefore, multiple proxies have been proposed to estimate NO flux in the field, such as laboratory incubation experiments (Bargsten et al., 2010; Schaufler et al., 2010; Yao et al., 2010), empirical models (Stark et al., 2002; Stehfest and Bouwman, 2006; Yan et al., 2005) and diffusion models (Galbally and Johansson, 1989; Remde et al., 1993; van Dijk et al., 2002). Comparing with the in-situ experiment, the laboratory incubation experiment is more suitable for investigating environmental factors regulating soil gas emissions, rather than quantifying the soil gas emission fluxes. Because when the soil cores were collected from the field, the corresponding soil environments would change. The empirical model is developed based on the relationship with NO flux and various environmental factors, such as soil temperature, soil water content and $\mathrm{N}$ availability, through large numbers of field measurements. However, due to the imbalanced work done in regions, this method will induce huge discrepancy in NO flux estimation.

As regards the diffusion model, it has been applied for various gases, such as $\mathrm{N}_{2} \mathrm{O}, \mathrm{CO}_{2}, \mathrm{CH}_{4}$ (Kusa et al., 2008; Pihlatie et al., 2007; Pumpanen et al., 2003), HONO (Su et al., 2011) and Hg (Wang et al., 2014; Zhang et al., 2002). This method is developed based on Fick's law of diffusion, concerning soil gas diffusion coefficient and concentration gradient between the uppermost soil layer and the atmosphere. The soil gas diffusion coefficient is related to soil properties, such as soil water content and soil tortuosity, which are spatially and temporally variable (Hutchinson and Livingston, 2002). Thus, this imprecision in estimating soil gas diffusion coefficient will result in large uncertainties in estimations of gas flux.

In this work, we propose a relative method based on gas diffusion principle in soil for measuring NO fluxes from forest soils, especially when the electric power supply system is unavailable. We first derive the formulation of this method, and then test this method though laboratory and field experiments with soil from an $\mathrm{N}$-saturated subtropical forest in Southwestern China.

\section{Methods}

\subsection{The principle of the relative method}

\subsubsection{Diffusion model}

Gas transportation through the soil profile occurs predominantly by diffusion process (Hutchinson and Livingston, 2002). Many reported works assumed that the soil gas diffusion coefficient was constant within the soil profile, and the sources or sinks of the target gas were negligible compared with the quantity of the gas transported by diffusion. Thus, the soil-atmosphere gas exchange flux could be calculated with the diffusion model based on Fick's law:

$$
\mathrm{F}=-\left(\mathrm{D}_{\mathrm{s}} / \mathrm{z}\right)\left(\mathrm{C}_{0}-\mathrm{C}_{\mathrm{g}}\right)=-\left(\mathrm{D}_{\mathrm{s}} / \mathrm{z}\right) \Delta \mathrm{C}
$$

where F represents the gas exchange flux between soil and atmosphere $\left(\mu \mathrm{g} \mathrm{m} \mathrm{m}^{-2} \mathrm{~h}^{-1}\right), \mathrm{D}_{\mathrm{s}}$ means the soil gas diffusion coefficient $\left(\mathrm{cm}^{2} \mathrm{~s}^{-1}\right)$, which primarily depends on gas properties and the corresponding soil conditions, such as soil air content and soil tortuosity, $\mathrm{z}$ is the soil vertical distance $(\mathrm{cm})$, and $\Delta C$ represents the gas concentration difference between the atmosphere $\left(C_{0}\left(\mu \mathrm{g} \mathrm{m}^{-3}\right)\right)$ and the uppermost soil layer $\left(\mathrm{C}_{\mathrm{g}}\left(\mu \mathrm{g} \mathrm{m}^{-3}\right)\right)$. The gas concentration in the uppermost soil layer $\left(C_{g}\right)$ can be expressed as two forms: the equilibrium concentration upon soil water surface $\left(C^{*}\right)$ (Su et al., 2011) and the directly obtained soil gas concentration $\left(C_{s}\right)$ (Kusa et al., 2008; Wolf et al., 2011a). In most ecosystems, the equilibrium between soil water and soil gas cannot be achieved. When large numbers of gases were produced in the soil, continuous gas emission from soil water to soil gas may occur. In this paper, we will introduce the method based on these two forms. 
We assumed that the soil water followed the ideal solution behavior (Su et al., 2011). The equilibrium gas concentration ( $\left.C^{*}\right)$ upon soil water surface can be calculated according to Henry's law:

$\mathrm{C}^{*}=\mathrm{C}_{\mathrm{l}} / \mathrm{K}_{\mathrm{H}}$

$\mathrm{K}_{\mathrm{H}}(\mathrm{T})=\mathrm{K}_{\mathrm{H}}^{\circ} \exp \left((1 / \mathrm{T}-1 / 298.15 \mathrm{~K}) \mathrm{dln}\left(\mathrm{K}_{\mathrm{H}}\right) / \mathrm{d}(1 / \mathrm{T})\right)$

where $C_{1}$ represents the dissolved gas concentration in soil water $\left(\mathrm{mol} \mathrm{L}^{-1}\right), \mathrm{K}_{\mathrm{H}}$ means Henry's law constant $\left(\mathrm{mol} \mathrm{atm}^{-1} \mathrm{~L}^{-1}\right), \mathrm{K}_{\mathrm{H}}^{\circ}$ represents the value of $\mathrm{K}_{\mathrm{H}}$ at $298.15 \mathrm{~K}\left(\mathrm{~mol} \mathrm{~atm}^{-1} \mathrm{~L}^{-1}\right)$, and $\mathrm{dln}\left(\mathrm{K}_{\mathrm{H}}\right) / \mathrm{d}(1 / \mathrm{T})$ indicates a temperature related factor.

The soil gas diffusion coefficient at certain temperature $D_{s}(T)$ $\left(\mathrm{cm}^{2} \mathrm{~s}^{-1}\right)$ can be calculated as follows: (Heincke and Kaupenjohann, 1999; Jin and Jury, 1996):

$\mathrm{D}_{\mathrm{s}}(\mathrm{T})=\left[\mathrm{D}_{0}\left(\mathrm{~T}_{0}\right)\left(\mathrm{T} / \mathrm{T}_{0}\right)^{1.81}\right] \theta_{\mathrm{g}}{ }^{2} \theta_{\mathrm{t}}^{-2 / 3}$

where $\theta_{\mathrm{g}}$ and $\theta_{\mathrm{t}}$ are the gas-fill porosity and total porosity in the soil $\left(\mathrm{cm}^{3} \mathrm{~cm}^{-3}\right)$, and $\mathrm{D}_{0}\left(\mathrm{~T}_{0}\right)$ represents the gas diffusion coefficient in the atmosphere at standard temperature $\left(\mathrm{cm}^{2} \mathrm{~s}^{-1}\right)$. The value of $\mathrm{D}_{0}\left(\mathrm{~T}_{0}\right)$ for target gas is constant and can be calculated by the CO62 method (Massman, 1998). For example, the $\mathrm{D}_{0}$ values for $\mathrm{N}_{2} \mathrm{O}, \mathrm{NO}$ and $\mathrm{CO}_{2}$ under standard temperature are $0.14,0.20$ and $0.14 \mathrm{~cm}^{2} \mathrm{~s}^{-1}$, respectively. The air-filled porosity $\left(\theta_{\mathrm{g}}\right)$ and total porosity in the soil $\left(\theta_{\mathrm{t}}\right)$ are given by (Davidson and Trumbore, 1995):

$\theta_{\mathrm{t}}=1-\frac{\rho_{\mathrm{b}}}{\rho_{\mathrm{d}}}$

$\theta_{\mathrm{g}}=\theta_{\mathrm{t}}-\omega$

where $\omega$ is the gravimetric water content $\left(\mathrm{mL} \mathrm{cm}^{-3}\right), \rho_{\mathrm{b}}$ represents the dry bulk density of the soil $\left(\mathrm{g} \mathrm{cm}^{-3}\right)$, and $\rho_{\mathrm{d}}$ means the particle density $\left(\mathrm{g} \mathrm{cm}^{-3}\right)$. However, these parameters are spatially and temporally variable. Large uncertainties will be induced in estimates of soil gas diffusion coefficient.

\subsubsection{The relative method}

In this paper, we assumed that the top soil layer was kinetically in steady-state, and the diffusion paths were the same for different soil gases. Thus, the corresponding soil characteristics, such as soil temperature, gas-fill porosity and total porosity, were the same. If we related the diffusion processes of two soil gases, such as $\mathrm{NO}$ and $\mathrm{N}_{2} \mathrm{O}$ or NO and $\mathrm{CO}_{2}$, as follows (Eqs. (7)-(8)), the uncertainty resulted from varying soil properties could be ignored and the gas diffusion coefficients in the soil ( $D_{1}^{s}$ and $D_{2}^{s}$ ) would be substituted by those in the air $\left(D_{1}^{0}\right.$ and $\mathrm{D}_{2}^{0}$ ):

$\frac{F_{1}}{F_{2}}=\frac{-D_{1}^{s}\left(C_{1}^{0}-C_{1}^{*}\right)}{-D_{2}^{s}\left(C_{2}^{0}-C_{2}^{*}\right)}=\frac{D_{1}^{0}}{D_{2}^{0}} \times \frac{\Delta C_{1}^{*}}{\Delta C_{2}^{*}}$

or

$\frac{F_{1}}{F_{2}}=\frac{-D_{1}^{s}\left(C_{1}^{0}-C_{1}^{S}\right)}{-D_{2}^{s}\left(C_{2}^{0}-C_{2}^{s}\right)}=\frac{D_{1}^{0}}{D_{2}^{0}} \times \frac{\Delta C_{1}^{s}}{\Delta C_{2}^{s}}$

where $\frac{F_{1}}{F_{2}}$ demonstrates linear correlation with $\frac{\Delta C_{1}^{*}}{\Delta C_{2}^{*}}$ or $\frac{\Delta C_{1}^{s}}{\Delta C_{2}^{s}}$, and the slope is
$\frac{\mathrm{D}_{1}^{0}}{\mathrm{D}_{2}^{0}}$. This equation can also be represented in the following:

$\frac{F_{1}}{F_{2}}=\left(\frac{D_{1}^{0} M_{1} K_{H}}{D_{2}^{0} M_{2} K_{H 1}} \times \frac{1-\frac{C_{1}^{0}}{C_{1}^{*}}}{1-\frac{C_{2}^{0}}{C_{2}^{*}}}\right) \times \frac{C_{1}^{1}}{C_{2}^{1}}$

or

$\frac{F_{1}}{F_{2}}=\left(\frac{D_{1}^{0}}{D_{2}^{0}} \times \frac{1-\frac{C_{1}^{0}}{C_{1}^{S}}}{1-\frac{C_{2}^{0}}{C_{2}^{S}}}\right) \times \frac{C_{1}^{S}}{C_{2}^{S}}$

where $M_{n}$ represent the relative molecular mass for observed gas. When both gases are largely produced in the soil $\left(\frac{\mathrm{C}_{1}^{0}}{\mathrm{C}_{1}}<23 \%\right.$ and $\frac{\mathrm{C}_{2}^{0}}{\mathrm{C}_{2}}<23 \%$ or $\frac{\mathrm{C}_{1}^{0}}{\mathrm{C}_{1}^{5}}<2$ $3 \%$ and $\frac{C_{2}^{0}}{C_{2}^{s}}<23 \%$, i.e.), gas concentrations in the atmosphere can be neglected and Eqs. (9)-(10) will be further simplified with the deviation rate lower than $30 \%$, which is within an acceptable range reported before for large-scale field experiments (Luo et al., 2012; Stehfest and Bouwman, 2006; van Dijk et al., 2002):

$\frac{F_{1}}{F_{2}}=\frac{D_{1}^{0} M_{1} K_{H 2}}{D_{2}^{0} M_{2} K_{H 1}} \times \frac{C_{1}^{l}}{C_{2}^{l}}$

or

$\frac{F_{1}}{F_{2}}=\frac{D_{1}^{0}}{D_{2}^{0}} \times \frac{C_{1}^{S}}{C_{2}^{S}}$

These equations show linear relationships between $\frac{F_{1}}{F_{2}}$ and $\frac{C_{1}^{d}}{C_{2}^{1}}$ or $\frac{C_{1}^{s}}{C_{2}^{S}}$, with $\frac{D_{1}^{0} \mathrm{M}_{1} \mathrm{~K}_{\mathrm{H} 2}}{\mathrm{D}_{2}^{0} \mathrm{M}_{2} \mathrm{~K}_{\mathrm{H} 1}}$ and $\frac{\mathrm{D}_{1}^{0}}{\mathrm{D}_{2}^{0}}$ as the slopes of the linear fitting. These theoretical slopes: $\frac{\mathrm{D}_{\mathrm{NO}^{\circ} \mathrm{M}_{\mathrm{NO}} \mathrm{K}_{\mathrm{HN}_{2} \mathrm{O}}}^{0}}{\mathrm{D}_{\mathrm{N}_{2} \mathrm{O}} \mathrm{M}_{\mathrm{N}_{2} \mathrm{O}} \mathrm{K}_{\mathrm{HNO}}} \frac{D_{\mathrm{N}_{2} \mathrm{O}}^{0} \mathrm{M}_{\mathrm{N}_{2} \mathrm{O}} \mathrm{K}_{\mathrm{HCO}_{2}}}{D_{\mathrm{CO}_{2}}^{0} \mathrm{M}_{\mathrm{CO}_{2}} \mathrm{~K}_{\mathrm{HN}_{2} \mathrm{O}}}$ and $\frac{\mathrm{D}_{\mathrm{NO}}^{0} \mathrm{M}_{\mathrm{NO} \mathrm{K}_{\mathrm{HCO}}}}{\mathrm{D}_{\mathrm{CO}_{2}}^{0} \mathrm{M}_{\mathrm{CO}_{2} \mathrm{~K}_{\mathrm{HNO}}}}$, can be calculated by empirical constants, and the values are $13.81,1.36$ and 18.84 , respectively. Similarly, the theoretical values of $\frac{\mathrm{D}_{\mathrm{NO}}^{0}}{\mathrm{D}_{\mathrm{N}_{2}}^{0} \mathrm{O}}, \frac{\mathrm{D}_{\mathrm{N}_{2} \mathrm{O}}^{0}}{\mathrm{D}_{\mathrm{CO}_{2}}^{0}}$ and $\frac{\mathrm{D}_{\mathrm{NO}}^{0}}{\mathrm{D}_{\mathrm{CO}_{2}}^{0}}$ are calculated as $1.44,0.98$ and 1.42 , respectively. Therefore, we can indirectly calculate $\mathrm{NO}$ fluxes through the relationship with the flux of $\mathrm{N}_{2} \mathrm{O}$ or $\mathrm{CO}_{2}$ by static chamber method.

\subsection{Testing the relative method in the laboratory}

The laboratory experiment was conducted with soil samples collected from Tieshanping $\left(29^{\circ} 38^{\prime} \mathrm{N} 104^{\circ} 41^{\prime} \mathrm{E}\right.$, TSP, for short), a Masson pinedominated subtropical forest, in Southwestern China (Fig. 1). TSP has suffered from high load of N-deposition for years $\left(>5 \mathrm{~g} \mathrm{~m}^{-2} \mathrm{yr}^{-1}\right)$. The mean annual temperature and rainfall is $18.2^{\circ} \mathrm{C}$ and $1028 \mathrm{~mm}$, with summer being the hottest and wettest period of the year. The soil is acid with the $\mathrm{pH}$ value of around 4. For further details about this measurement site, see Zhu et al. (2013). During the laboratory experiment, the water doses applied followed the rainfall in TSP on weekly basis. Thus the soil would experience wetting-drying cycles. The room temperature was kept at around $20^{\circ} \mathrm{C}$, assuring appropriate conditions for microbial activities and enough $\mathrm{NO}, \mathrm{N}_{2} \mathrm{O}$ and $\mathrm{CO}_{2}$ production in the soil. In order to establish this relative method, the soil-atmosphere exchange fluxes, dissolved gas concentrations in soil water and soil gas concentrations of $\mathrm{NO}, \mathrm{N}_{2} \mathrm{O}$ and $\mathrm{CO}_{2}$ were observed simultaneously. 


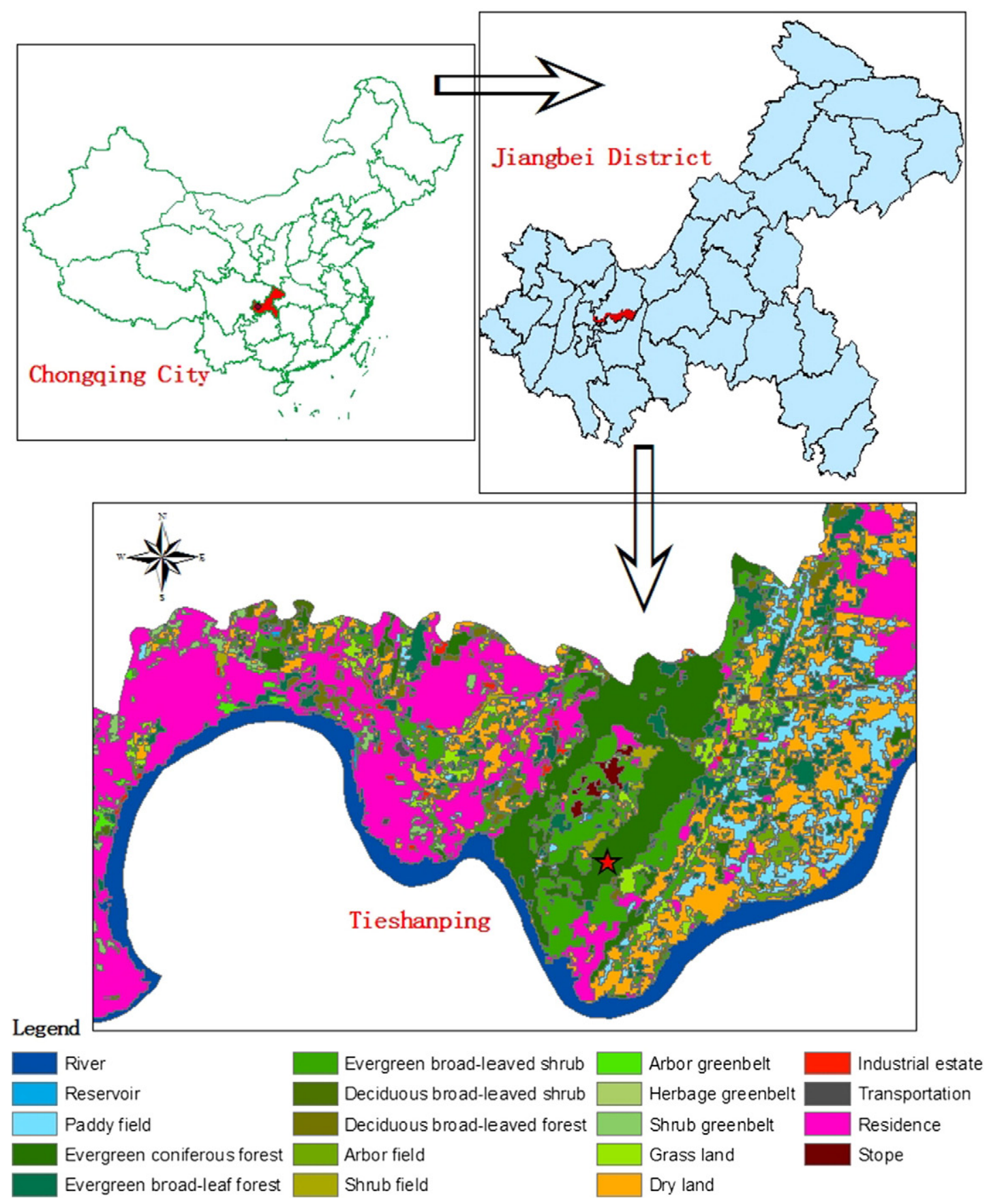

Fig. 1. Location of the Tieshanping (TSP) forest catchment, Chongqing, China.

\subsubsection{Measurements of soil-atmosphere exchange fluxes}

During the laboratory experiment, $\mathrm{NO}, \mathrm{N}_{2} \mathrm{O}$ and $\mathrm{CO}_{2}$ fluxes were measured by an improved static chamber method (Fig. 2). The chamber is a cylinder made of PVC ( $20.50 \mathrm{~cm}$ in height and the cross-sectional diameter is $26.50 \mathrm{~cm}$ ). During the whole period, the chamber was treated with light avoidance, and hence any potential photolytic processes, such as $\mathrm{OH}$ and $\mathrm{VOC}$ production, will not take place in the chamber. Before experiment, the chamber was flushed with dry synthetic air (free from $\mathrm{NO}$ and $\left.\mathrm{O}_{3}\right) 10 \mathrm{~min}$ with the flow rate of $10 \mathrm{~L} \mathrm{~min}^{-1}$ to reduce the $\mathrm{O}_{3}$ concentration level in the chamber (approximately $99.50 \%$ lower than that in the ambient air), so as to exclude the potential oxidation process from $\mathrm{NO}$ to $\mathrm{NO}_{2}$ by $\mathrm{O}_{3}$. Simultaneously, the chamber was shield from the soil with a Teflon cover without disturbing the soil surface. At the top of the chamber, a three-way valve and an inflatable
Teflon bag were installed for gas samples collection and pressure-buffering, respectively. The gas samples were taken with a $50 \mathrm{~mL}$ syringe. To mix the chamber air, the syringe should be filled and flushed three times before sampling. During the observation time-period, $40 \mathrm{~mL}$ gas was taken for NO analyses at an interval of $5 \mathrm{~min}$ and the sampling period lasted $20 \mathrm{~min}$. Another $10 \mathrm{~mL}$ gas sample for $\mathrm{N}_{2} \mathrm{O}$ and $\mathrm{CO}_{2}$ analyses was obtained by pre-evacuated $10 \mathrm{~mL}$ glass vials at every turn. Our main interest of the laboratory experiment was in verifying the relative method, with no aim to reproduce the gas flux under actual experiment condition.

NO concentration was determined discontinuously by a NO-NO $x$ analyzer (Thermo Fisher 42i, chemiluminescence detector, USA). Gas samples were injected into the gas stream of NO-free high-purify argon gas to the detector. The detection limit is $1.62 \mu \mathrm{g} \mathrm{m}^{-3}$. The NO-NO $\mathrm{x}$ analyzer 


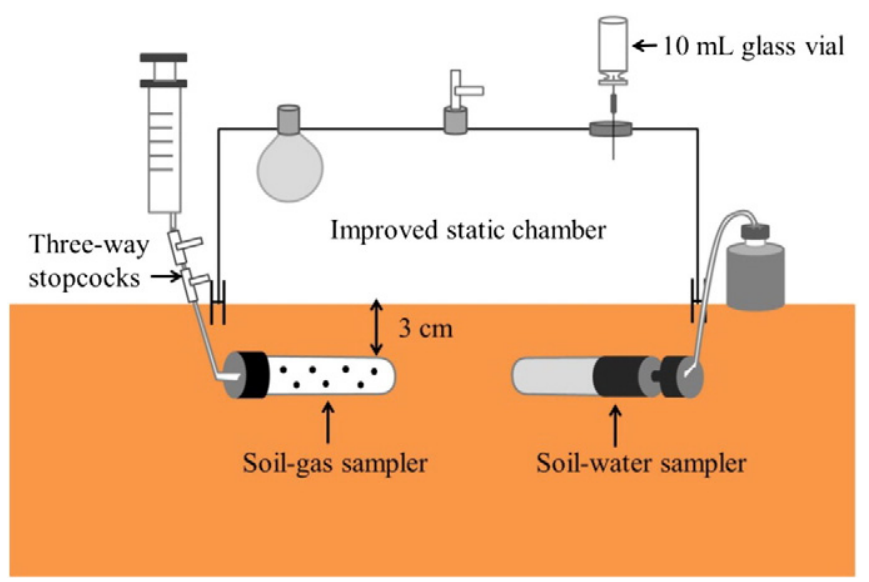

Fig. 2. Schematic of the set-up of improved static chamber, soil gas and soil water samplers.

was calibrated by varying the amount of $\mathrm{NO}$ standard gas mixed with purified argon (free of $\mathrm{NO}$ ). The concentrations of $\mathrm{N}_{2} \mathrm{O}$ and $\mathrm{CO}_{2}$ were analyzed by Agilent 7890 gas chromatography, equipped with an electron capture detector and a flame ionization detector.

\subsubsection{Measurements of soil gas concentrations}

Previous experiments showed that soil gases, such as $\mathrm{N}_{2} \mathrm{O}$ and NO, were mostly produced and consumed within the uppermost soil layer (0-0.1 m), which is characterized by high content of organic material (Bargsten et al., 2010; Ludwig et al., 2001; Pihlatie et al., 2007). For this reason, the soil water and soil gas samplers, in this work, were both installed horizontally in triplicate at the depth of $3 \mathrm{~cm}$ right below the chamber (Fig. 2). After we installed the samplers, the soil was consolidated for several rain events prior to first gas sampling.

Soil gases were collected from perforated PVC samplers (radius $0.75 \mathrm{~cm}$, height $11 \mathrm{~cm}$ ) through Teflon tubes, equipped with threeway valves. Our soil gas sampler was a kind of active sampler. During each sampling, the initial $30 \mathrm{~mL}$ of the soil gas from the sampling line and sampling tube was rejected, and then another $40 \mathrm{~mL}$ soil gas sample was drawn into a $50 \mathrm{~mL}$ syringe for $\mathrm{NO}$ analysis. In order to avoid photochemical reactions, the gas samples should be covered by aluminum foil. Another $10 \mathrm{~mL}$ gas sample for $\mathrm{N}_{2} \mathrm{O}$ and $\mathrm{CO}_{2}$ analysis was transferred to a pre-evacuated $10 \mathrm{~mL}$ glass vial.

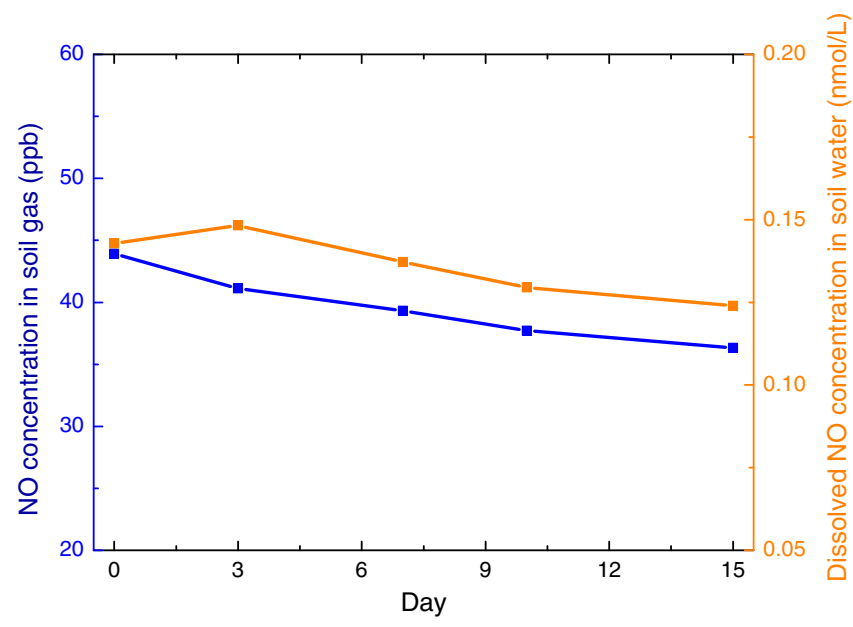

Fig. 3. NO concentration variations in soil gas and soil water during preservation experiment.
The appropriate soil gas volume sampled each time should depend on the collecting depth of soil layer and the soil volumetric water content (Nauer et al., 2013). In a homogeneous soil, the shape of the soil from which the soil gas is withdrawn can be simplified as an annular column around the sampler (Fig. S1). When the soil gas sampler was set at the depth of $3 \mathrm{~cm}$, the outer radius of this annular column should not exceed $3.75 \mathrm{~cm}$, otherwise the sampled soil gas would be diluted by air upon soil surface. This corresponded to a maximum volume of $466 \mathrm{~mL}$ for the annular column. Hence, when the soil air-filled porosity was $0.5 \mathrm{~m}^{3} \mathrm{~m}^{-3}$, the safe gas sampling volume should be $<233 \mathrm{~mL}$. During the soil gas sampling period, about $80 \mathrm{~mL}$ soil gas was needed. This was within the maximum volume. Besides, our pre-field experiment demonstrated that the measured soil gas concentration was not affected by the ambient gas (Fig. S2).

We have conducted preservation experiment for soil NO concentration analysis in the laboratory. $300 \mathrm{~mL}$ soil gas was sampled and preserved in a $1 \mathrm{~L}$ Teflon bag for well mix. Then we immediately transferred the soil gas from the Teflon bag into five $50 \mathrm{~mL}$ syringes covered by aluminum foil. During the experiment, these gas samples were analyzed after $0,3,7,10$ and 15 days, respectively. The results showed that $\mathrm{NO}$ gas in the soil could be reserved for 15 days, with the deviation rate of $7.50 \%$ (Fig. 3).

\subsubsection{Measurements of dissolved gas concentrations in soil water}

The dissolved gas concentrations in soil water were analyzed by headspace equilibration technique (Cole and Caraco, 2001; Huang et al., 2013; Moraghan and Buresh, 1977). Soil water was collected by ceramic suction cup lysimeter (P80; Staatliche Porzellanmanufaktur, Berlin) with a three-stopcock assembly. The soil gas were filled out and only the soil water could pass into the sampler. To ensure the accuracy of the dissolved gas concentration in soil water, each soil water sampler should be tested for leakage before installing. Before each sampling, the residual soil water in the sampler was discharged. Then about $25 \mathrm{~mL}$ soil water was collected with a $100 \mathrm{~mL}$ pre-evacuated glass vial. During the whole sampling period, glass vials were covered by black drawstring bags to avoid direct sunlight.

The weights of the glass vial before and after soil water sampling should be measured to calculate the aqueous $\left(\mathrm{V}_{\mathrm{vl}}(\mathrm{L})\right)$ and gaseous volume $\left(\mathrm{V}_{\mathrm{vg}}(\mathrm{L})\right)$ in the glass vial. After soil water sampling, we use highpurify argon (free from $\mathrm{NO}, \mathrm{N}_{2} \mathrm{O}$ and $\mathrm{CO}_{2}$ ) to equilibrate the glass vial pressure. The glass vial was shaken vigorously for 2 min by hand, allowing fully equilibration of the air and water phase. Then the headspace gas was pushed out by water flowing automatically by gravity, making sure that the headspace gas was under standard atmospheric pressure. A $40 \mathrm{~mL}$ gas sample was collected for $\mathrm{NO}$ analysis and another $10 \mathrm{~mL}$ gas was stored in a $10 \mathrm{~mL}$ pre-evacuated glass vial for $\mathrm{N}_{2} \mathrm{O}$ and $\mathrm{CO}_{2}$ analysis. The dissolved gas concentration in soil water $\left(\mathrm{C}_{1}\right.$ $\left.\left(\mathrm{mol} \mathrm{L}^{-1}\right)\right)$ can be calculated in the following:

$\mathrm{C}_{\mathrm{l}}=\left(\mathrm{C}_{\mathrm{vg}} \mathrm{V}_{\mathrm{vg}}+\mathrm{C}_{\mathrm{vl}} \mathrm{V}_{\mathrm{vl}}\right) / \mathrm{V}_{\mathrm{vl}}$

$\mathrm{C}_{\mathrm{vl}}=\mathrm{C}_{\mathrm{vg}} \mathrm{K}_{\mathrm{H}}$

where $C_{v g}$ indicates the gas concentration in the headspace of the glass vial ( $\mathrm{mol} \mathrm{L}^{-1}$ or atm) and $\mathrm{C}_{\mathrm{vl}}$ represents the dissolved gas concentration in the water collected in the glass vial $\left(\mathrm{mol} \mathrm{L}^{-1}\right)$. In this work, Eqs. (13)-(14) can be applied to calculate dissolved $\mathrm{CO}_{2}$ concentration because the soil pH value in TSP is around 4 with $\mathrm{CO}_{2}$ as the only existent form in the soil water.

The preservation experiment for NO gas dissolved in soil water has also been conducted. During the experiment, soil water samples were collected into five $100 \mathrm{~mL}$ glass vials covered by black drawstring bags, and these samples were analyzed after 0, 3, 7, 10 and 15 days, 

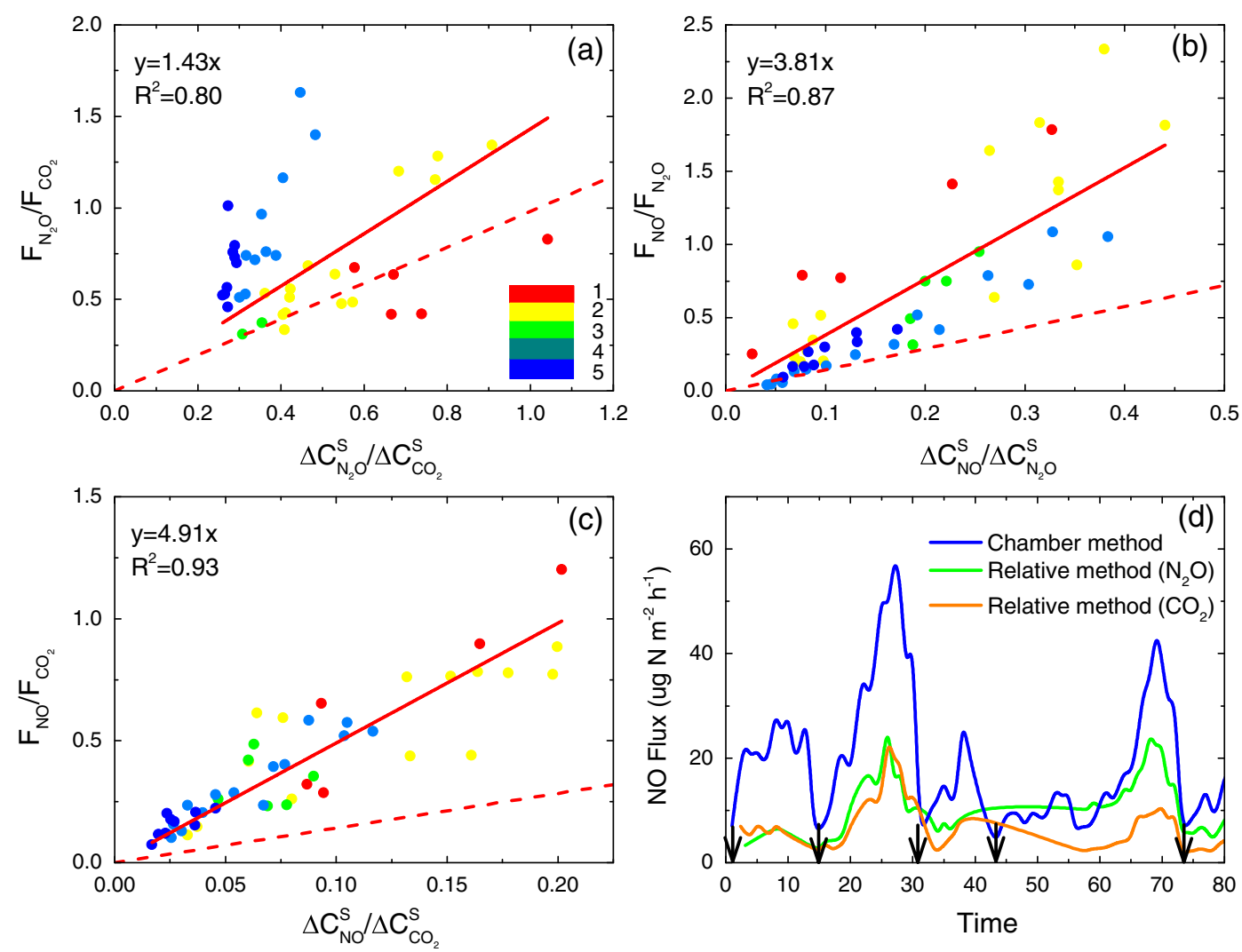

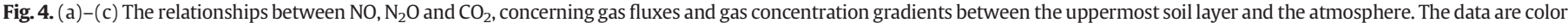

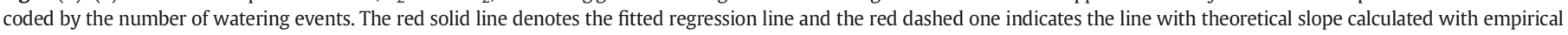

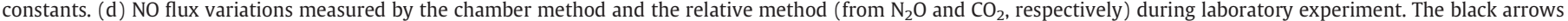
indicate the watering events.

respectively. The results showed that the soil water samples could be reserved for at least 15 days, with the deviation rate of $7.19 \%$ (Fig. 3).

\subsection{The field experiments}

In order to testify the applicability of this relative method in the forest ecosystem, the field experiment was conducted in TSP from July 2014 to June 2015 covering four consecutive seasons. To represent the subtropical forest characteristics in south central China, we selected a 4.6 ha forested head water catchment in TSP, with $96.4 \%$ consisted of North-faced hill slopes (HS) and the remainder consisted of ground water discharge zone (GDZ). The dominant soil types in HS and GDZ are clay-rich loamy yellow mountain soil and colluvium soil, respectively. Four sampling plots were selected along these two hydrologically-connected transects, with plot A at the top of HS, plot B at the bottom of HS, plot $C$ at the interface between HS and GDZ, and plot D at GDZ.

In the field experiment, gas flux measurements for $\mathrm{N}_{2} \mathrm{O}$ and $\mathrm{CO}_{2}$ were conducted with traditional static chamber made of stainless steel (40 cm $\times 40 \mathrm{~cm}$, height $15 \mathrm{~cm}$ ). During each sampling period, $10 \mathrm{~mL}$ gas was taken by pre-evacuated $10 \mathrm{~mL}$ glass vial from the chamber at an interval of 5 min after the enclosure of the chamber. The sampling period lasted $20 \mathrm{~min}$. The direct NO flux measurements with dynamic chamber method were only available in A and B sampling plots from July to August 2015, and the details will be shown in a companion paper, supported by Norwegian University of Life Sciences. The soil gas and soil water sampling processes were the same as those described in Section 2.2

\section{Results and discussions}

\subsection{Testing the relative method in the laboratory}

\subsubsection{The relative method based on soil gas}

During the laboratory experiment, several watering events were conducted, ensuring that the incubated soil experimented several drywet cycles. The correlation plot in Fig. 4a shows a poor linear regression between $\frac{\mathrm{F}_{\mathrm{N}_{2} \mathrm{O}}}{\mathrm{F}_{\mathrm{CO}_{2}}}$ and $\frac{\Delta \mathrm{C}_{\mathrm{N}_{2} \mathrm{O}}^{\mathrm{s}}}{\Delta \mathrm{C}_{\mathrm{CO}_{2}}^{\mathrm{S}}}$, with a slope of $1.43\left(\mathrm{R}^{2}=0.80\right)$. Note that this relationship varied with different soil conditions, which was induced by watering events. This indicates that when the investigated soil experienced different soil environments, the uncertainty resulted from the changeable soil characteristics could not be overcame. Comparing with this poor relationship, we found better linear correlations between $\frac{\mathrm{F}_{\mathrm{NO}}}{\mathrm{F}_{\mathrm{N}_{2} \mathrm{O}}}$ and $\frac{\Delta \mathrm{C}_{\mathrm{NO}}^{\mathrm{s}}}{\Delta \mathrm{C}_{\mathrm{N}_{2} \mathrm{O}}^{\mathrm{O}}}\left(\mathrm{R}^{2}=0.87, P<0.01\right)$, and between $\frac{\mathrm{F}_{\mathrm{NO}}}{\mathrm{F}_{\mathrm{CO}_{2}}}$ and $\frac{\Delta \mathrm{C}_{\mathrm{NO}}^{s}}{\Delta \mathrm{C}_{\mathrm{CO}_{2}}^{\mathrm{s}}}\left(\mathrm{R}^{2}=0.93\right.$, $\mathrm{P}<0.01$ ) in Fig. 4b and Fig. 4c. These slopes of linear fitting were, however, both largely strayed from what should be expected from empirical constants $\left(\frac{\mathrm{D}_{\mathrm{NO}}^{0}}{\mathrm{D}_{\mathrm{N}_{2} \mathrm{O}}^{\mathrm{O}}}=1.44\right.$ and $\left.\frac{\mathrm{D}_{\mathrm{NO}}^{0}}{\mathrm{D}_{\mathrm{CO}_{2}}^{0}}=1.42\right)$, with the deviation rates of $164.58 \%$ and $245.77 \%$, respectively.

Furthermore, we made a comparison between NO flux measurements made by the chamber method and the relative method based on the relationship between $\frac{F_{N O}}{F_{N_{2} O} \mathrm{O}}$ and $\frac{\Delta C_{N O}^{s}}{\Delta C_{\mathrm{N}_{2} \mathrm{O}}^{\mathrm{S}}}$ or between $\frac{\mathrm{F}_{\mathrm{NO}}}{\mathrm{F}_{\mathrm{CO}_{2}}}$ and $\frac{\Delta \mathrm{C}_{\mathrm{NO}}^{\mathrm{s}}}{\Delta \mathrm{C}_{\mathrm{CO}_{2}}^{\mathrm{s}}}$ in Fig. 4d. The NO fluxes measured by the relative method demonstrated similar variation pattern as those by the chamber method: the value dropped to the lowest point after watering events and gradually increased to the top with soil moisture decreasing. Nevertheless, 

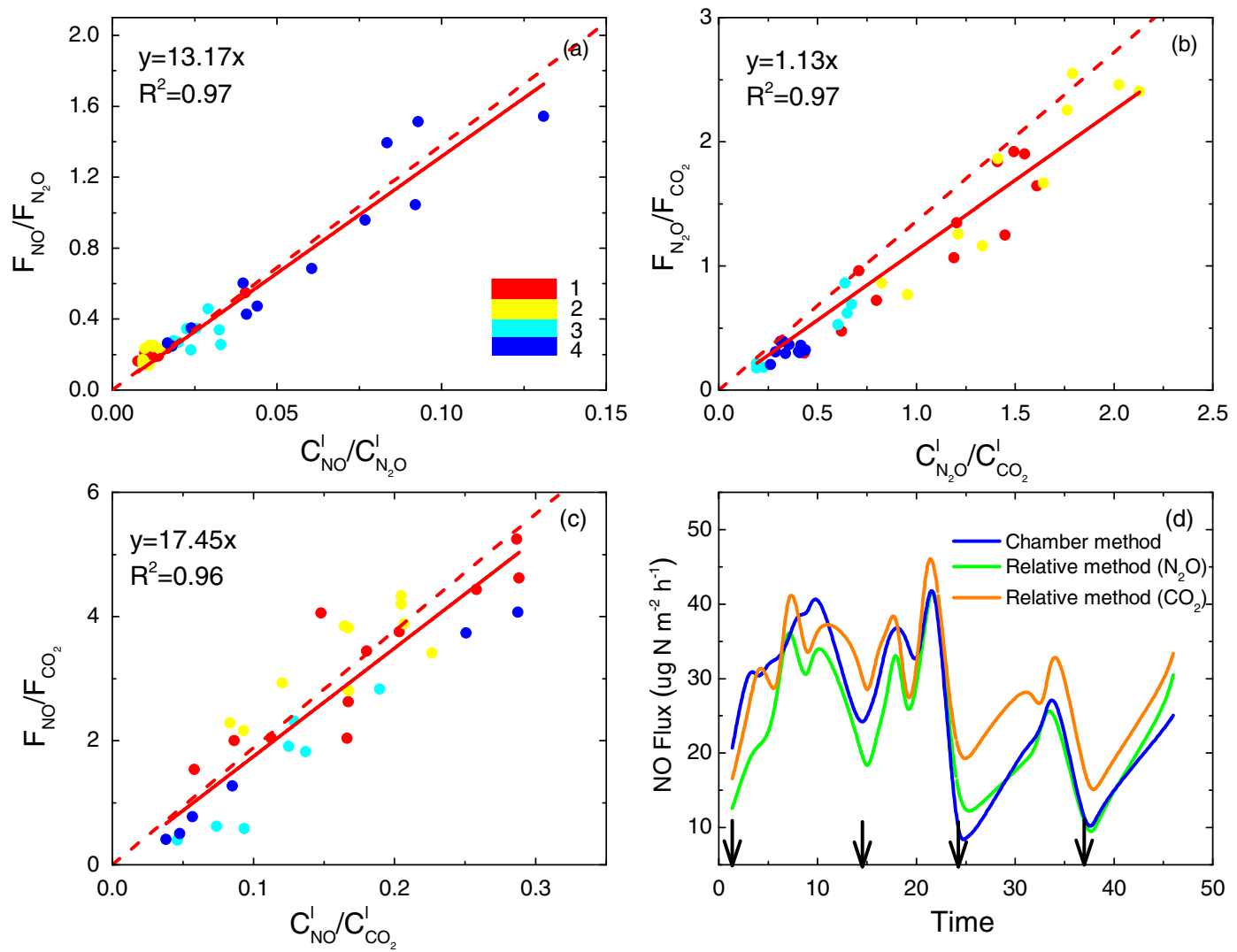

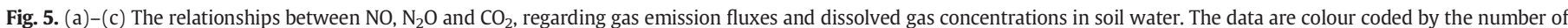

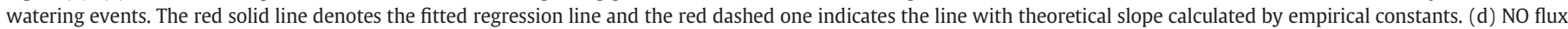

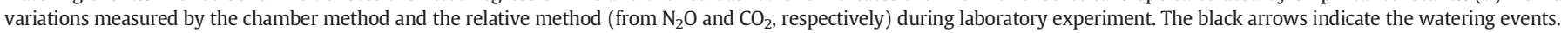

comparing with the chamber-based NO fluxes, the calculated fluxes were both significantly underestimated. The preceding dissatisfactory results, therefore, represented that the feasibility of this method based on soil gas to evaluate NO flux variation was still questionable and we should further conduct field experiments to assess it.

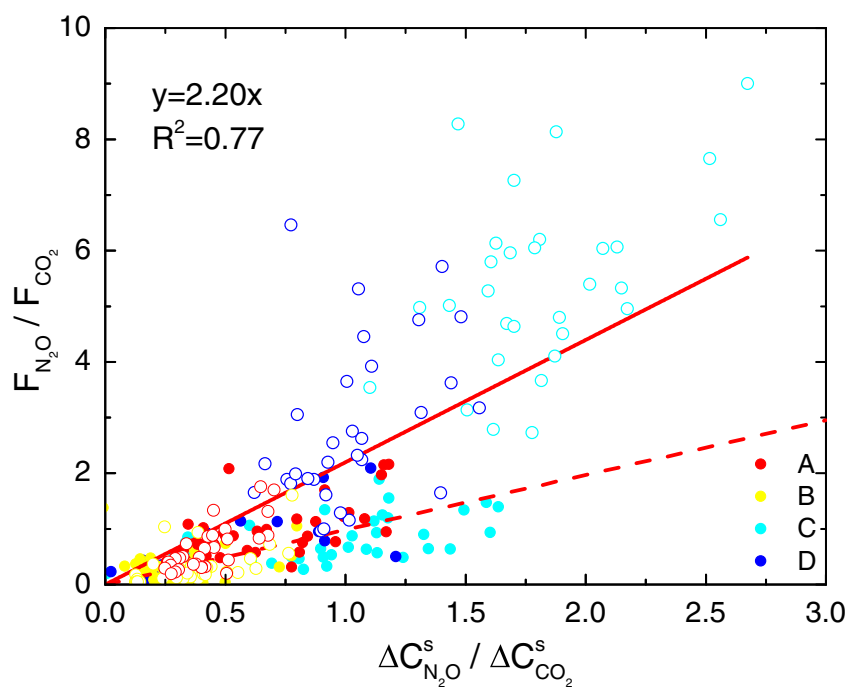

Fig. 6. The relationship between $\mathrm{N}_{2} \mathrm{O}$ and $\mathrm{CO}_{2}$, concerning gas emission fluxes and gas concentration gradients between the uppermost soil layer and the atmosphere in TSP. The red solid line denotes the regression line and the red dash-dotted one indicates the theoretical line calculated by empirical constants. The hollow points represent the data collected during summer campaign.

\subsubsection{The relative method based on soil water}

In Fig. 5, significant linear correlations were found between $\frac{\mathrm{F}_{\mathrm{NO}}}{\mathrm{F}_{\mathrm{N}_{2} \mathrm{O}}}$ and $\frac{C_{\mathrm{NO}}^{1}}{C_{\mathrm{N}_{2} \mathrm{O}}}\left(\mathrm{R}^{2}=0.97, P<0.01\right), \frac{\mathrm{F}_{\mathrm{N}_{2} \mathrm{O}}}{\mathrm{F}_{\mathrm{CO}_{2}}}$ and $\frac{\mathrm{C}_{\mathrm{N}_{2} \mathrm{O}}^{1}}{\mathrm{C}_{\mathrm{CO}_{2}}^{2}}\left(R^{2}=0.97, \mathrm{P}<0.01\right)$, as well as between $\frac{\mathrm{F}_{\mathrm{NO}}}{\mathrm{F}_{\mathrm{CO}_{2}}}$ and $\frac{\mathrm{C}_{\mathrm{NO}}^{1}}{\mathrm{C}_{\mathrm{CO}_{2}}}\left(\mathrm{R}^{2}=0.96, \mathrm{P}<0.01\right)$, when investigated soil experienced multiple watering evens. These slopes all agreed well with the theoretical ones calculated with empirical constants $\left(\frac{\mathrm{D}_{\mathrm{NO}_{0}}^{0} \mathrm{M}_{\mathrm{NO} \mathrm{K}_{\mathrm{H}_{2} \mathrm{O}} \mathrm{O}}}{\overline{\mathrm{N}}_{\mathrm{N}_{2} \mathrm{O}} \mathrm{M}_{\mathrm{N}_{2} \mathrm{O}} \mathrm{K}_{\mathrm{HNO}}}=13\right.$. $\left.81, \frac{D_{\mathrm{N}_{2} \mathrm{O}}^{0} \mathrm{M}_{\mathrm{N}_{2} \mathrm{O}} \mathrm{K}_{\mathrm{HCO}_{2}}}{\mathrm{D}_{\mathrm{CO}_{2}} \mathrm{M}_{\mathrm{CO}_{2}} \mathrm{~K}_{\mathrm{HN}_{2} \mathrm{O}}}=1.36, \frac{\mathrm{D}_{\mathrm{NO}_{0}}^{0} \mathrm{M}_{\mathrm{NO}} \mathrm{K}_{\mathrm{HCO}_{2}}}{\mathrm{D}_{\mathrm{CO}_{2}}^{0} \mathrm{M}_{\mathrm{CO}_{2}} \mathrm{~K}_{\mathrm{HNO}}}=18.84\right)$, with the deviation rates of $4.63 \%, 16.91 \%$ and $7.38 \%$, respectively. These small deviations indicated that this relative method based on soil water was irrelevant to soil conditions.

In order to examine the capability of this method to evaluate NO flux variations, the comparison between NO fluxes measured by the chamber method and the relative method (based on the relationship between $\frac{\mathrm{F}_{\mathrm{NO}}}{\mathrm{F}_{\mathrm{N}_{2} \mathrm{O}}}$ and $\frac{\mathrm{C}_{\mathrm{NO}}^{1}}{\mathrm{C}_{\mathrm{N}_{2} \mathrm{O}} \mathrm{O}}$ or between $\frac{\mathrm{F}_{\mathrm{NO}}}{\mathrm{F}_{\mathrm{CO}_{2}}}$ and $\frac{\mathrm{C}_{\mathrm{NO}}^{\mathrm{l}}}{\mathrm{C}_{\mathrm{CO}_{2}}^{\mathrm{N}}}$ ) was showed in Fig. $5 \mathrm{~d}$. We found that the calculated NO fluxes agreed well with the observed values, and the variation patter closely resembled that previously reported in Fig. 4d, with NO flux dropping to the lowest point after watering events and gradually increasing when soil moisture decreased. These differences between NO fluxes measured by chamber method and the relative method from $\mathrm{N}_{2} \mathrm{O}$ and $\mathrm{CO}_{2}$ were both significantly lower (around 9\%). This good consistency showed during the wet-dry cycles further identified that this method was suitable for measuring NO fluxes. In the next section, we will investigate the capability of this relative method to interpret NO flux variations in the forest ecosystem. 


\subsection{Testing the relative method by field measurements}

\subsubsection{The relative method based on soil gas}

The field experiments in TSP have covered multiple seasons and sampling plots. The investigated soil experienced characteristic wet and dry soil conditions, with the soil water filled pore space (WFPS) ranging from $7 \%$ to $63 \%$. The average soil temperature value varied from $6.92{ }^{\circ} \mathrm{C}$ in winter to $26.19{ }^{\circ} \mathrm{C}$ in summer. The correlation plot in Fig. 6 shows a poor relationship between $\frac{\mathrm{F}_{\mathrm{N}_{2} \mathrm{O}}}{\mathrm{F}_{\mathrm{CO}_{2}}}$ and $\frac{\Delta \mathrm{C}_{\mathrm{N}_{2} \mathrm{O}}^{\mathrm{S}}}{\Delta \mathrm{CO}_{\mathrm{CO}_{2}}^{5}}$, with $\mathrm{R}^{2}$ value of $0.77(N=282, P<0.01)$. Consistent with the dissatisfactory results represented in Fig. $4 \mathrm{a}$, the slope of the linear regression shown here also intensively strayed away from the expected value $\left(\frac{\mathrm{D}_{\mathrm{N}_{2} \mathrm{O}}^{0}}{\mathrm{D}_{\mathrm{C}_{2}}}=0.98\right)$, with the deviation rate of $124.49 \%$. We found that this significant discrepancy happened when the upmost soil layer was extremely unsteady, particularly in summer when intense bacteria activities happened upon the soil gas sampler.

Then, we applied the relative method based on soil gas to measure NO fluxes in TSP from July to August 2014. The average NO fluxes calculated according to the relationship between $\frac{\mathrm{F}_{\mathrm{NO}}}{\mathrm{F}_{\mathrm{N}_{2} \mathrm{O}}}$ and $\frac{\Delta \mathrm{C}_{\mathrm{NO}}^{\mathrm{S}}}{\Delta \mathrm{C}_{\mathrm{N}_{2} \mathrm{O}}}(6.01 \pm$ $5.52 \mu \mathrm{g} \mathrm{N} \mathrm{m}{ }^{-2} \mathrm{~h}^{-1}$ and $11.08 \pm 1.65 \mu \mathrm{g} \mathrm{N} \mathrm{m}{ }^{-2} \mathrm{~h}^{-1}$ ) were, as expected, much lower than those measured with chamber method (12.01 \pm $12.03 \mu \mathrm{g} \mathrm{N} \mathrm{m}^{-2} \mathrm{~h}^{-1}$ and $\left.34.05 \pm 36.17 \mu \mathrm{g} \mathrm{N} \mathrm{m}{ }^{-2} \mathrm{~h}^{-1}\right)$ in $\mathrm{A}$ and $\mathrm{B}$ two sampling plots. The correlation analysis and the comparison results confirmed that the relative method based on soil gas was unsuitable for NO flux estimation in the field.

Here we attribute these dissatisfactory results to the potential biological activities that happened upon the samplers. When introducing this relative method, we assumed that the upmost soil layer was in steady state, and only considered the physical transportation process in the soil profile. However, even though we can install the soil gas samplers as close as to the soil surface layer, we cannot avoid but only reduce the influence from potential biological activities. If biological activities happened upon soil gas samplers, the time scale of soil gas diffusion process would be larger than that affecting the soil gas concentration difference. Thus, the emission fluxes measured by the relative method will be over- or underestimated. Previous studies that compared flux measurements by the chamber method and the diffusion

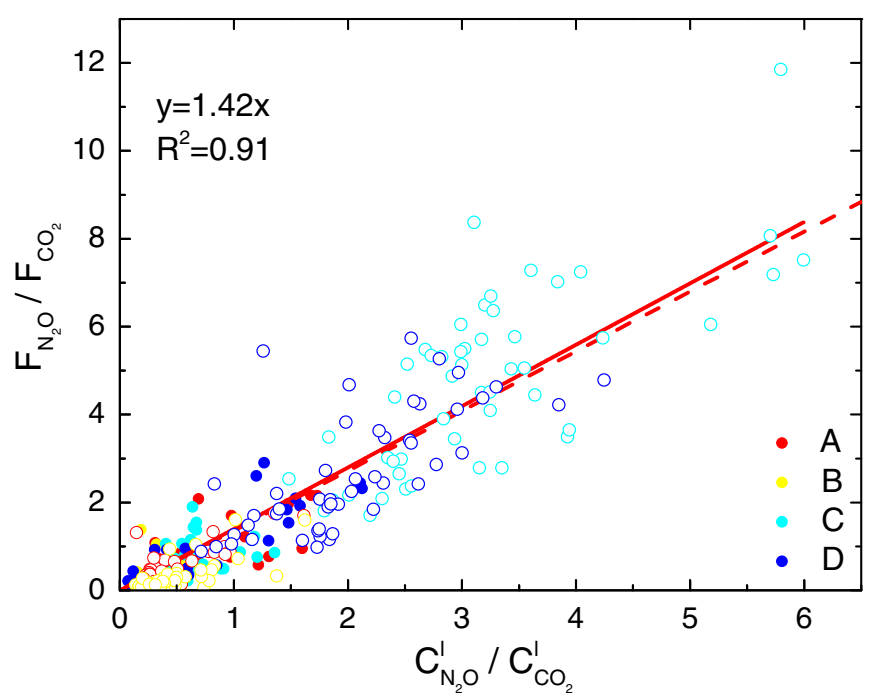

Fig. 7. The relationship between $\mathrm{N}_{2} \mathrm{O}$ and $\mathrm{CO}_{2}$, concerning gas fluxes and dissolved gas concentrations in soil water in TSP. The red solid line denotes the regression line and the red dashed one indicates the theoretical line calculated by empirical constants. The hollow points represent the data collected during summer campaign. model based on the directly obtained soil gas have yielded mixed results. For example, Kusa et al. (2008) found no significant difference between the $\mathrm{N}_{2} \mathrm{O}$ fluxes measured by these two methods. However, the comparison results by Pihlatie et al. (2007) represented that the $\mathrm{N}_{2} \mathrm{O}$ fluxes measured by the diffusion method were higher and more variable than those by chamber method. Wolf et al. (2011a) found that the differences between these two methods ranged from $-3.4 \%$ to $20 \%$ and from $40.7 \%$ to $76.9 \%$, respectively, for $\mathrm{CO}_{2}$ and $\mathrm{N}_{2} \mathrm{O}$ flux measurements.

\subsubsection{The relative method based on soil water}

The correlation plot in Fig. 7 represents a remarkable linear relationship between $\frac{\mathrm{F}_{\mathrm{N}_{2} \mathrm{O}}}{\mathrm{F}_{\mathrm{CO}_{2}}}$ and $\frac{\mathrm{C}_{\mathrm{N}_{2} \mathrm{O}}^{\mathrm{O}}}{\mathrm{C}_{\mathrm{CO}_{2}}^{\mathrm{l}}}$, with $\mathrm{R}^{2}$ value of $0.91(N=344, P<0.01)$. This linear regression agreed well with the theoretically developed one and the deviation rate $(4.41 \%)$ was unexpectedly lower than that in the laboratory experiment (16.91\%). We attributed this lower deviation rate to the larger time and space span covered in the field experiment. Note that this linear correlation can be achieved even in summer, when the upmost soil layer was extremely unsteady: large numbers of soil gases were produced or consumed. The good correlation and consistency further indicated that, with the relative method based on soil water, the proposed hypothesis: if we related the diffusion processes of two soil gases, the uncertainty resulted from varying soil properties could be effectively overcame, can be applicable in the field.

Furthermore, we applied this relative method base on soil water for NO fluxes measurement from July to August 2014. Considering the entire summer campaign, there was good agreement between the chamber-based values $\left(12.01 \pm 12.03 \mu \mathrm{g} \mathrm{N} \mathrm{m}{ }^{-2} \mathrm{~h}^{-1}\right.$ and $34.05 \pm$ $36.17 \mu \mathrm{g} \mathrm{N} \mathrm{m}^{-2} \mathrm{~h}^{-1}$ ) and those calculated based upon the relationship between $\frac{\mathrm{F}_{\mathrm{NO}}}{\mathrm{F}_{\mathrm{N}_{2} \mathrm{O}}}$ and $\frac{\mathrm{C}_{\mathrm{NO}}^{1}}{\mathrm{C}_{\mathrm{N}_{2} \mathrm{O}}}\left(10.37 \pm 3.06 \mu \mathrm{g} \mathrm{N} \mathrm{m}^{-2} \mathrm{~h}^{-1}\right.$ and $23.32 \pm$ $5.86 \mu \mathrm{g} \mathrm{N} \mathrm{m}^{-2} \mathrm{~h}^{-1}$ ) in A and B two sampling plots, with the deviation rates of $13.66 \%$ and $31.54 \%$, respectively. Therefore, we concluded that the relative method based on soil water can act as a promising alternate for NO flux measurements in the field.

In contrast to the directly obtain soil gas, some researchers (Remde et al., 1993; van Dijk et al., 2002) have proposed a theoretically steady-state soil gas, which reached the point when gas-producing and gas-consuming processes balanced each other, to evaluate NO flux variation. Considering the superiority of the relative method based on soil water, we inferred that the equilibrium gas upon soil water surface could better depict the theoretically steady-state soil gas. Biological activities, such as nitrification and denitrification processes, generally take place in the soil water. Thus, the equilibrium gas concentration upon soil water surface is the integrated product of gas production and consumption through serials of biological reactions. Our conclusion was consistent with the work by Su et al. (2011), which found that the theoretically equilibrium HONO concentration in the upmost soil layer could well interpret the HONO soil-atmosphere exchange flux through chamber experiment. However, preceding analysis merely depended upon our experiment results and hypothesis. It is meaningful if more intensive and convincing experiments, such as relating to biological activities, are carried out to disclose further detail about this issue.

\section{Conclusions}

In this paper we presented and tested a relative method for the measurements of NO flux from forest soils. Our laboratory experiments and the measurements in the field demonstrated that this method based on soil water was suitable for NO flux measurements in the forest ecosystem. During both laboratory and field experiments, the NO fluxes calculated by the relationship between $\frac{F_{\mathrm{NO}}}{F_{\mathrm{N}_{2} \mathrm{O}}}$ and $\frac{C_{\mathrm{NO}}^{1}}{C_{\mathrm{N}_{2} \mathrm{O}}}$ agreed well with the chamberbased flux measurements. The good correlation between $\frac{\mathrm{F}_{\mathrm{N}_{2} \mathrm{O}}}{\mathrm{F}_{\mathrm{CO}_{2}}}$ and $\frac{\mathrm{C}_{\mathrm{N}_{2} \mathrm{O}}^{\mathrm{O}}}{\mathrm{C}_{\mathrm{CO}_{2}}}$ 
found in the field from July 2014 to June 2015 indirectly validated the capability of this relative method to measure NO fluxes over large timescale, for instance to establish seasonal variations within an ecosystem. The preservation experiment showed that the filtered soil water samples could be kept in room temperature for several days or more for $\mathrm{NO}$ analysis, so our method was convenient for regional investigation of NO fluxes. In conclusion, the relative method based on soil water acts as a promising proxy to measure NO fluxes in the forest ecosystem, particularly where the power system is unavailable, and then contributes to profile the inventory of $\mathrm{NO}$ emission in the world. Additionally, our relative method may provide a methodological basis for the flux measurements of other nitrogen-containing gases, such as nitrous acid (HONO), which has been proven challenging in the world. However, the application of this method should be explored further; more intensive and convincing experiments are needed.

\section{Acknowledgments and data}

This work was financially supported by Research Council of Norway (Norklima209696/E10) and Chinese Academy of Science (GJHZ1205, KZCX2-YW-GJ01).

\section{Appendix A. Supplementary data}

Supplementary data to this article can be found online at http://dx. doi.org/10.1016/j.scitotenv.2016.09.012.

\section{References}

Bargsten, A., Falge, E., Pritsch, K., Huwe, B., Meixner, F.X., 2010. Laboratory measurements of nitric oxide release from forest soil with a thick organic layer under different understory types. Biogeosciences 7, 1425-1441.

Buhlmann, T., Hiltbrunner, E., Korner, C., Rihm, B., Achermann, B., 2015. Induction of indirect $\mathrm{N}_{2} \mathrm{O}$ and $\mathrm{NO}$ emissions by atmospheric nitrogen deposition in (semi-)natural ecosystems in Switzerland. Atmos. Environ. 103, 94-101.

Cole, J.J., Caraco, N.F., 2001. Emissions of nitrous oxide $\left(\mathrm{N}_{2} \mathrm{O}\right)$ from a tidal, freshwater river, the Hudson River, New York. Environ. Sci. Technol. 35, 991-996.

Crutzen, P.J., 1979. Role of $\mathrm{NO}$ and $\mathrm{NO}_{2}$ in the chemistry of the troposphere and stratosphere. Ann. Rev. Earth Pl. Sci. 7, 443-472.

Davidson, E.A., Kingerlee, W., 1997. A global inventory of nitric oxide emissions from soils. Nutr. Cycl. Agroecosyst. 48, 37-50.

Davidson, E.A., Trumbore, S.E., 1995. Gas diffusivity and production of $\mathrm{CO}_{2}$ in deep soils of the eastern amazon. Tellus B 47, 550-565.

Erickson, H.E., Perakis, S.S., 2014. Soil fluxes of methane, nitrous oxide, and nitric oxide from aggrading forests in coastal Oregon. Soil Biol. Biochem. 76, 268-277.

Galbally, I.E., Johansson, C., 1989. A model relating laboratory measurements of rates of nitric oxide production and field measurements of nitric oxide emission from soils. J. Geophys. Res. 94, 6473-6480.

Galbally, I.E., Roy, C.R., 1978. Loss of fixed nitrogen from soils by nitric-oxide exhalation. Nature 275, 734-735.

Heincke, M., Kaupenjohann, M., 1999. Effects of soil solution on the dynamics of $\mathrm{N}_{2} \mathrm{O}$ emissions: a review. Nutr. Cycl. Agroecosyst. 55, 133-157.

Huang, L., Gao, X., Guo, J., Ma, X., Liu, M., 2013. A review on the mechanism and affecting factors of nitrous oxide emission in constructed wetlands. Environ. Earth Sci. 68, 2171-2180.

Hutchinson, G.L., Livingston, G.P., 2002. Soil-Atmosphere Gas Exchange. In: Dane, J.H. Topp, C.G. (Eds.), Methods of Soil Analysis: Part 4 Physical Methods. Soil Sci Soc Am J, Madison, WI, pp. 1159-1182.

Jin, Y., Jury, W.A., 1996. Characterizing the dependence of gas diffusion coefficient on soil properties. Soil Sci. Soc. Am. J. 60, 66-71.

Kusa, K., Sawamoto, T., Hu, R., Hatano, R., 2008. Comparison of the closed-chamber and gas concentration gradient methods for measurement of $\mathrm{CO}_{2}$ and $\mathrm{N}_{2} \mathrm{O}$ fluxes in two upland field soils. Soil Sci. Plant Nutr. 54, 777-785.

Li, D., Wang, X.M., Mo, J.M., Sheng, G.Y., Fu, J., 2007. Soil nitric oxide emissions from two subtropical humid forests in south China. J. Geophys. Res. 112, D23302.

Li, D., Wang, X., Sheng, G., Mo, J., Fu, J., 2008. Soil nitric oxide emissions after nitrogen and phosphorus additions in two subtropical humid forests. J. Geophys. Res. 113, D16301.

Lu, C.Q., Tian, H.Q., 2007. Spatial and temporal patterns of nitrogen deposition in China: Synthesis of observational data. J. Geophys. Res. 112, D22S05.

Ludwig, J., Meixner, F.X., Vogel, B., Forstner, J., 2001. Soil-air exchange of nitric oxide: an overview of processes, dnvironmental vactors, and modeling studies. Biogeochemistry $52,225-257$.

Luo, G.J., Bruggemann, N., Wolf, B., Gasche, R., Grote, R., Butterbach-Bahl, K., 2012. Decadal variability of soil $\mathrm{CO}_{2}, \mathrm{NO}, \mathrm{N}_{2} \mathrm{O}$, and $\mathrm{CH}_{4}$ fluxes at the Hoglwald Forest, Germany. Biogeosciences 9, 1741-1763.

Massman, W.J., 1998. A review of the molecular diffusivities of $\mathrm{H}_{2} \mathrm{O}, \mathrm{CO}_{2}, \mathrm{CH}_{4}, \mathrm{CO}, \mathrm{O}_{3}, \mathrm{SO}_{2}$, $\mathrm{NH}_{3}, \mathrm{~N}_{2} \mathrm{O}, \mathrm{NO}$, and $\mathrm{NO}_{2}$ in air, $\mathrm{O}_{2}$ and $\mathrm{N}_{2}$ near STP. Atmos. Environ. 32, 1111-1127.
Medinets, S., Skiba, U., Rennenberg, H., Butterbach-Bahl, K., 2015. A review of soil NO transformation: associated processes and possible physiological significance on organisms. Soil Biol. Biochem. 80, 92-117.

Mei, B., Zheng, X., Xie, B., Dong, H., Zhou, Z., Wang, R., et al., 2009. Nitric oxide emissions from conventional vegetable fields in southeastern China. Atmos. Environ. 43, 2762-2769.

Moraghan, J.T., Buresh, R., 1977. Correction for dissolved nitrous oxide in nitrogen studies. Soil Sci. Soc. Am. J. 41, 1201-1202.

Nauer, P.A., Chiri, E., Schroth, M.H., 2013. Poly-use multi-level sampling system for soilgas transport analysis in the vadose zone. Environ. Sci. Technol. 47, 11122-11130.

Nishina, K., Takenaka, C., Ishizuka, S., 2009. Spatial variations in nitrous oxide and nitric oxide emission potential on a slope of Japanese cedar (Cryptomeria japonica) forest Soil Sci. Plant Nutr. 55, 179-189.

Pihlatie, M., Pumpanen, J., Rinne, J., Ilvesniemi, H., Simojoki, A., Hari, P., et al., 2007. Gas concentration driven fluxes of nitrous oxide and carbon dioxide in boreal forest soil. Tellus B 59, 458-469.

Pilegaard, K., Skiba, U., Ambus, P., Beier, C., Brueggemann, N., Butterbach-Bahl, K., et al., 2006. Factors controlling regional differences in forest soil emission of nitrogen oxides ( $\mathrm{NO}$ and $\mathrm{N}_{2} \mathrm{O}$ ). Biogeosciences 3, 651-661.

Pumpanen, J., Ilvesniemi, H., Hari, P., 2003. A process-based model for predicting soil carbon dioxide efflux and concentration. Soil Sci. Soc. Am. J. 67, 402-413.

Purbopuspito, J., Veldkamp, E., Brumme, R., Murdiyarso, D., 2006. Trace gas fluxes and nitrogen cycling along an elevation sequence of tropical montane forests in Central Sulawesi, Indonesia. Glob. Biogeochem. Cycles 20, GB3010.

Remde, A., Ludwig, J., Meixner, F.X., Conrad, R., 1993. A study to explain the emission of nitric-oxide from a marsh soil. J. Atmos. Chem. 17, 249-275.

Schaufler, G., Kitzler, B., Schindlbacher, A., Skiba, U., Sutton, M.A., ZechmeisterBoltenstern, S., 2010. Greenhouse gas emissions from European soils under different land use: effects of soil moisture and temperature. Eur. J. Soil Sci. 61, 683-696.

Schindlbacher, A., Zechmeister-Boltenstern, S., Butterbach-Bahl, K., 2004. Effects of soil moisture and temperature on $\mathrm{NO}, \mathrm{NO}_{2}$, and $\mathrm{N}_{2} \mathrm{O}$ emissions from European forest soils. J. Geophys. Res. 109, D17302.

Skiba, U., Sheppard, L., Pitcairn, C.E.R., Leith, I., Crossley, A., van Dijk, S., et al., 1998. Soil nitrous oxide and nitric oxide emissions as indicators of elevated atmospheric $\mathrm{N}$ deposition rates in seminatural ecosystems. Environ. Pollut. 102, 457-461.

Stark, J.M., Smart, D.R., Hart, S.C., Haubensak, K.A., 2002. Regulation of nitric oxide emissions from forest and rangeland soils of western North America. Ecology 83, 2278-2292.

Stehfest, E., Bouwman, L., 2006. $\mathrm{N}_{2} \mathrm{O}$ and NO emission from agricultural fields and soils under natural vegetation: summarizing available measurement data and modeling of global annual emissions. Nutr. Cycl. Agroecosyst. 74, 207-228.

Su, H., Cheng, Y., Oswald, R., Behrendt, T., Trebs, I., Meixner, F.X., et al., 2011. Soil nitrite as a source of atmospheric HONO and OH radicals. Science 333, 1616-1618.

van Dijk, S.M., Duyzer, J.H., 1999. Nitric oxide emissions from forest soils. J. Geophys. Res. 104, 15955-15961.

van Dijk, S.M., Gut, A., Kirkman, G.A., Meixner, F.X., Andreae, M.O., BM, G., 2002. Biogenic NO emissions from forest and pasture soils: relating laboratory studies to field measurements. J. Geophys. Res. 107 (LBA 25-1-LBA 25-11).

Venterea, R.T., Groffman, P.M., Verchot, L.V., Magill, A.H., Aber, J.D., Steudler, P.A., 2003. Nitrogen oxide gas emissions from temperate forest soils receiving long-term nitrogen inputs. Glob. Chang. Biol. 9, 346-357.

Wang, X., Lin, C.J., Feng, X., 2014. Sensitivity analysis of an updated bidirectional air-surface exchange model for elemental mercury vapor. Atmos. Chem. Phys. 14, 6273-6287.

Wolf, B., Chen, W., Brüggemann, N., Zheng, X., Pumpanen, J., Butterbach-Bahl, K., 2011a. Applicability of the soil gradient method for estimating soil-atmosphere $\mathrm{CO}_{2}, \mathrm{CH}_{4}$ and $\mathrm{N}_{2} \mathrm{O}$ fluxes for steppe soils in Inner Mongolia. J. Soil Sci. Plant Nutr. 174, 359-372.

Wolf, K., Veldkamp, E., Homeier, J., Martinson, G.O., 2011b. Nitrogen availability links forest productivity, soil nitrous oxide and nitric oxide fluxes of a tropical montane forest in southern Ecuador. Glob. Biogeochem. Cycles 25, GB4009.

Wu, X., Bruggemann, N., Gasche, R., Shen, Z.Y., Wolf, B., Butterbach-Bahl, K., 2010. Environmental controls over soil-atmosphere exchange of $\mathrm{N}_{2} \mathrm{O}, \mathrm{NO}$, and $\mathrm{CO}_{2}$ in a temperate Norway spruce forest. Glob. Biogeochem. Cycles 24, GB2012.

Yan, X.Y., Ohara, T., Akimoto, I., 2005. Statistical modeling of global soil $\mathrm{NO}_{\mathrm{x}}$ emissions. Glob. Biogeochem. Cycles 19, GB3019.

Yao, Z.S., Wu, X., Wolf, B., Dannenmann, M., Butterbach-Bahl, K., Brueggemann, N., et al., 2010. Soil-atmosphere exchange potential of $\mathrm{NO}$ and $\mathrm{N}_{2} \mathrm{O}$ in different land use types of Inner Mongolia as affected by soil temperature, soil moisture, freeze-thaw, and drying-wetting events. J. Geophys. Res. 115, D17116.

Zhang, Y.J., Lin, F., Jin, Y.G., Wang, X.F., Liu, S.W., Zou, J.W., 2016b. Response of nitric and nitrous oxide fluxes to $\mathrm{N}$ fertilizer application in greenhouse vegetable cropping systems in southeast China. Sci. Rep. 6, 20700.

Zhang, H., Lindberg, S.E., Barnett, M.O., Vette, A.F., Gustin, M.S., 2002. Dynamic flux chamber measurement of gaseous mercury emission fluxes over soils. Part 1: simulation of gaseous mercury emissions from soils using a two-resistance exchange interface model. Atmos. Environ. 36, 835-846.

Zhang, Y., Mu, Y., Zhou, Y., Tian, D., Liu, J., Zhang, C., 2016a. NO and $\mathrm{N}_{2} \mathrm{O}$ emissions from agricultural fields in the North China Plain: origination and mitigation. Sci. Total Environ. 551-552, 197-204.

Zhu, J., Mulder, J., Wu, L.P., Meng, X.X., Wang, Y.H., Dorsch, P., 2013. Spatial and temporal variability of $\mathrm{N}_{2} \mathrm{O}$ emissions in a subtropical forest catchment in China. Biogeosciences 10,1309-1321. 